\title{
Customary Law in Hungary: Courts, Texts and the Tripartitum.
}

By MARTYN RADY. Pp. 288. Oxford: Oxford University Press. 2015. £60.00.

Hardback. ISBN: 9780188743910.

The title of Martyn Rady's most recent book - Customary Law in Hungary: Courts, Texts and Tripartitum - illuminates the enlightening scope of Rady's scholarship and the commendable breadth of his investigation. This work is significant not purely because it is the first comprehensive study of Hungarian customary law in any language — and thus opens annals for further inquiry - but also because of its range. It provides discussions on private, public, constitutional and procedural law from the thirteenth- to the twentieth-century. Notwithstanding this coverage, because of Rady's seamless writing, his main arguments are easy to locate: (1) that written codification of customary law did not make the law any less customary, rather it provided the courts with a heightened memory; (2) that Werbőczy's text was a mediation of his opinions of what ought to be the case, rather than a definitive legal commentary. Rady arrives at his conclusion after thorough evaluation and discussion on a multitude of primary sources, including the Tripartitum, and rigorous historiographical evaluations.

In the first two chapters, Rady neatly introduces customary law, the Tripartitum, the life of Werbőczy, as well as highlighting the problems that his discussion faces and how customary law has developed over time. From there, Rady works thematically through the book, considering: customary law and its legislation; medieval courts; the King, nobility and their relationship with one another and their land; prosecution; medieval procedure; the impacts of the Tripartitum; and succeeding codification attempts. In the last two chapters, Rady offers a chronological picture of customary law spanning from the eighteenth- to the twentieth-century.

This book benefits from Rady's extensive knowledge not only on the Hungarian and Latin languages but also his commitment to central European history and his longstanding research interests into customary law. His previous research and publications on the Golden Bull have clearly inspired the writing of this book with a good deal of Chapter 5 offering discussion on the implications and weaknesses of the resistance clause. As an editor and translator of Hungarian medieval chronicles, Rady also provides the reader with an insight into and an unmatched knowledge of important primary sources, for example the royal letters and charters discussed in Chapter 3.

Typically, a discussion on legal history, let alone one spanning seven hundred years, can be uninspiring; however, this is not the case here. I am particularly fond of his frequent use of the phrase "in what follows" as it allows the reader to continuously evaluate where they are in the text and - most importantly - Rady's argument. Similarly, statements like, 'let us examine in detail how the loca credibilia operated in respect of the kingdom's judicial administration' (p. 39) also add to the clarity of Rady's argumentation. Furthermore, Rady is an anecdotal writer and accordingly readers of all experiences will welcome the fact that his writing is heavily rooted in primary sources and tales. Not only does this make the book more accessible, but also more engaging, which helps when approaching such a stiff topic.

Whilst his book may be intriguing, there are certainly areas that have been left unexplored by Rady, for example how customary law affects Hungarian law and society today. This is peculiar not only because Rady makes the importance of customary law clear throughout the book, but also because he alludes to such a discussion in his final line. Rady writes: 'it embodies an older jurisprudence that may by its appeal to a popular comprehension of the law still influence the reasoning of lawyers and politicians' (p. 246). The closest he gets to such an investigation is a comparison between the 1959 Hungarian Civil Code and the Tripartitum; however, even that is relegated to the conclusion and 


\title{
67 REVIEWS: BOOKS
}

boasts no more than two paragraphs. Whilst it does not make Rady's book any weaker and I appreciate that he may not be interested in such an examination, I certainly think it would be beneficial to have included such an assessment. This is not only because it is an area unexplored by historians, but also because it is a link that students would not necessarily make independently. I cannot help but feel that Rady's investigation would have been fuller, if such a discussion were considered.

Ultimately, the occasional set back is meagre in light of the achievements of his book. Not only is it a welcomed addition to the scholarship of Hungarian, but also legal, feudal and central European histories.

\author{
MATTHEW MARTIN \\ School of Slavonic and East European Studies \\ University College London
}

This work is licensed under the Creative Commons Attribution-NonCommercial-ShareAlike 4.0 International License. This license lets others remix, tweak, and build upon work non-commercially, as long as they credit the author and license their new creations under the identical terms. To view a copy of this license, visit http:/ / creativecommons.org/licenses/by-nc-sa/4.0/. 